\title{
Seleksi Bakteri Asam Laktat dan Pemanfaatannya Sebagai Starter Kering Menggunakan Matriks Tapioka Asam
}

\author{
IRA ERDIANDINI ${ }^{1}$, TITI CANDRA SUNARTI ${ }^{2}$, ANJA MERYANDINI ${ }^{3 *}$

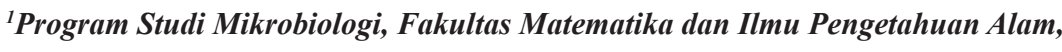 \\ Institut Pertanian Bogor, Dramaga IPB, Bogor, Jawa Barat, 16680 Indonesia \\ ${ }^{2}$ Departemen Teknologi Industri Pertanian, Fakultas Teknologi Pertanian, \\ Institut Pertanian Bogor, Dramaga IPB, Bogor, Jawa Barat, 16680 Indonesia \\ ${ }^{3}$ Departemen Biologi, Fakultas Matematika dan Ilmu Pengetahuan Alam, \\ Institut Pertanian Bogor, Dramaga IPB, Bogor, Jawa Barat, 16680 Indonesia
}

Diterima 28 November 2014/Disetujui 29 Desember 2014

\begin{abstract}
The development of industrial fermentation food could not separate with the availability of culture starter that suffice to support its production. Dried starter can be an option to use in fermentation industry because it can be stored for longer time without rejuvenation. However, in the process of production of dried starter needs the matrix to maintain cell viability, economically and availability of raw material. This research was conducted to use selected dried starter of indigenous lactic acid bacteria by using sour cassava starch matrix. Eleven local isolates lactic acid bacteria isolates from spontaneous fermentation of carbohydrates commodity were selected based on their acid production capabilities and antibiotics susceptibilities. Isolate of $\mathbf{E} 1222$ showed the best result and was identified as Pediococcus pentosaceus. The isolate was encapsulated with sour cassava starch matrix for making dried starter by using freeze dryer and spray dryer. Freeze dried starter culture could maintained the cell viability higher than spray dried starter culture i.e 10.34 $\log$ CFU/g and $8.91 \log$ CFU/g, respectively. Finally, freeze dried starter culture could maintain the percentage of cell viability until $89.38 \%$ during four-weeks storage at $4{ }^{\circ} \mathrm{C}$.
\end{abstract}

Key words: dried starter, lactic acid bacteria, sour cassava starch, freeze drying, spray drying

\section{PENDAHULUAN}

Bakteri asam laktat (BAL) merupakan bakteri Gram-positif yang banyak digunakan sebagai starter fermentasi. BAL mengeksresikan asam laktat sebagai produk akhir fermentasi yang berperan sebagai preservasi bahan makanan (Schnurer dan Magnusson 2005). Pemanfaatan BAL sebagai starter telah digunakan untuk berbagai fermentasi produk makanan seperti keju (Gomez-Ruiz et al. 2008), susu (Wang et al. 2012), daging (Liu et al. 2010), dan tepung (Putri et al. 2011). Seleksi terhadap galur BAL yang digunakan sebagai starter penting dilakukan untuk mengefektifkan proses fermentasi, meningkatkan kualitas produk akhir, dan aman bagi mikroorganisme lain di dalam tubuh (Stanbury \& Whitaker 1984). Dua kriteria penting yang digunakan untuk seleksi tersebut yaitu kemampuan produksi asam laktat dan sensitivitas antibiotik. Beberapa dekade terakhir, BAL yang digunakan sebagai starter fermentasi diketahui dapat menjadi reservoir gen resisten antibiotik (Hummel et al. 2007). Toomey

*Penulis korespondensi. Phone/Fax: +62-251-8622833, E-mail: ameryandini@yahoo.com et al. (2010) menemukan bahwa sebelas galur Enterococci, Lactobacilli dan Streptococci resisten eritromisin terdeteksi membawa gen erm(B) dan msrA/B. Kastner et al. (2006) menemukan adanya gen resisten tetrasiklin tet $(\mathrm{W})$ pada galur yang digunakan sebagai kultur starter fermentasi daging. BAL yang resisten terhadap antibiotik dapat mentransfer sifat resistensinya pada bakteri patogen maupun bakteri asam laktat lain (Toomey et al. 2010). Penggunaan BAL yang tidak resisten antibiotik sebagai starter fermentasi diharapkan dapat mengurangi penyebaran sifat resistensi antibiotik terutama terhadap bakteri patogen.

Kriteria lain BAL yang dapat digunakan sebagai starter kering fermentasi makanan yaitu memiliki memiliki viabilitas tinggi setelah proses preservasi dan stabil selama proses penyimpanan (Carvalho et al. 2004; Peighambardoust et al. 2011). Enkapsulasi telah lama dikenal sebagai teknologi preservasi BAL yang efektif untuk meningkatkan viabilitas sel dan mempertahankannya selama proses penyimpanan (Nazzaro et al. 2012). Enkapsulasi merupakan metode jerapan suatu substansi ke dalam substansi lain, menghasilkan partikel dalam ukuran nanometer 
(nanoenkapsulasi), mikrometer (mikroenkapsulasi) atau dalam skala milimeter (Burgain et al. 2011). Metode mikroenkapsulasi kultur bakteri yang sering digunakan yaitu pengeringan beku (freeze drying) dan pengeringan semprot (spray drying) (Morgan et al. 2006; Peighambardoust et al. 2011). Yao et al. (2009) memproduksi kultur starter fermentasi Gari menggunakan metode freeze drying. Lian et al. (2002) mampu mempertahankan tingkat ketahanan sel Bifidobacteria setelah spray drying mencapai $82.6 \%$.

Keberhasilan proses enkapsulasi dipengaruhi oleh jenis matriks yang digunakan. Matriks merupakan bahan enkapsulan yang digunakan untuk penyalut dan melapisi BAL pada proses enkapsulasi (Nazzaro et al. 2012). Matriks harus mampu berperan sebagai pelindung bagi BAL, aman dikonsumsi dan harganya murah sehingga harga produk akhir menjadi ekonomis. Salah satu bahan baku matriks yang harganya murah, tersedia melimpah, renewable, biodegradable dan non toksik ialah pati (Winarti et al. 2013). Pati merupakan makromolekul organik yang terdiri atas rantai-rantai monomer yang dihubungkan oleh ikatan kovalen. Struktur kimia dan konformasi rantai monomer menjadikan pati memiliki kemampuan membentuk gel sehingga dapat digunakan sebagai matriks dalam proses enkapsulasi mikroorganisme (Gbassi \& Vandamme 2012). Tapioka asam merupakan pati termodifikasi dari tapioka alami yang diproduksi melalui proses fermentasi. Tapioka asam berpotensi untuk digunakan sebagai matriks enkapsulasi BAL karena memiliki beberapa kelebihan. Pertama, tapioka asam diproduksi melalui proses fermentasi oleh BAL sehingga dapat digunakan sebagai bahan enkapsulan yang baik juga bagi BAL. Kedua, cara produksi yang alami pada tapioka asam menyebabkan tidak adanya kandungan BTP (Bahan Tambahan Pangan) yang berbahaya bagi mikroorganisme. Ketiga, proses fermentasi pada tapioka asam menyebabkan pemutusan polisakarida menjadi monosakarida yang bermanfaat sebagai protektan selama proses pengeringan dan penyimpanan. Berbagai kelebihan tapioka asam tersebut sekaligus ketersediaan bahan baku yang melimpah menyebabkan tapioka asam potensial untuk digunakan sebagai matriks enkapsulasi, namun penelitian mengenai produksi starter kering BAL menggunakan matriks tapioka asam belum banyak dilakukan. Produksi starter kering BAL menggunakan matriks tapioka asam diharapkan dapat meningkatkan ketersediaan starter BAL yang ekonomis untuk fermentasi makanan.

\section{BAHAN DAN METODE}

Seleksi Bakteri Asam Laktat (BAL). Sebelas isolat yang digunakan dalam penelitian ini merupakan koleksi Laboratorium Mikrobiologi, Departemen Biologi, Fakultas MIPA IPB. Sebelas isolat BAL lokal tersebut berasal dari fermentasi spontan jagung (E1212, E1211, E2211, E2113.5, E2112, E1222, E2121) (Rosyidah 2013) dan fermentasi spontan sagu (D3, D4, D5, D7) (Suseno 2015). Seleksi BAL lokal dilakukan terhadap kemampuan produksi asam dan sensitivitas antibiotik. Kemampuan isolat BAL dalam memproduksi asam dilakukan dengan menghitung total asam tertitrasi (AOAC 1995) dan pengukuran $\mathrm{pH}$ menggunakan $\mathrm{pH}$ meter. Uji sensitivitas antibiotik dilakukan dengan metode difusi cakram terhadap antibiotik tertrasiklin, eritromisin, dan kloramfenikol. Interpretasi sensitivitas isolat terhadap antibiotik yang diujikan dilakukan menggunakan standar Johnson dan Case (2007). Isolat yang memproduksi total asam tinggi dan tidak resisten terhadap antibiotik yang diujikan kemudian diukur kemampuan produksi asam laktatnya menggunakan HPLC (High Performance Liquid Chromatography). Isolat terpilih merupakan isolat yang memproduksi asam laktat paling tinggi, yang kemudian digunakan untuk uji selanjutnya.

Karakterisasi Isolat Terpilih. Karakterisasi isolat terpilih meliputi karakter mikroskopik dan pembuatan kurva tumbuh. Pengamatan karakter mikroskopik dilakukan menggunakan mikroskop cahaya meliputi hasil pewarnaan Gram dan bentuk sel. Pembuatan kurva tumbuh dilakukan dengan menginokulasikan kultur bakteri berumur 24 jam pada media MRSB (de Man Rogose Sharpe Broth). Kurva tumbuh diamati dengan melakukan perhitungan jumlah sel $(\log \mathrm{CFU} / \mathrm{mL})$ dan pengukuran terhadap OD menggunakan spektrofotometer pada panjang gelombang $(\lambda) 620 \mathrm{~nm}$. Perhitungan jumlah sel dilakukan dengan metode total plate count (TPC) pada media MRSA dan diinkubasi pada suhu $37^{\circ} \mathrm{C}$ selama 48 jam. Pengamatan dilakukan setiap satu jam hingga sel bakteri mencapai tingkat pertumbuhan spesifik maksimal $\left(\mu_{\mathrm{m}}, \mathrm{h}^{-1}\right)$.

Produksi Starter Kering. Produksi starter kering untuk isolat terpilih dilakukan dengan alat freeze dryer dan spray dryer menggunakan matriks tapioka asam. Sebanyak $500 \mathrm{~mL}$ sampel disiapkan dengan mencampurkan $450 \mathrm{~mL}$ larutan matriks steril $1 \%(\mathrm{~b} / \mathrm{v})$ dengan $50 \mathrm{~mL}$ kultur BAL pada tahap pertumbuhan optimum. Perlakuan matriks tapioka asam dengan penambahan susu skim sebesar $10 \%(\mathrm{~b} / \mathrm{b})$ dari total bobot matriks, digunakan 
sebagai kontrol positif. Susu skim yang digunakan sebelumnya dilarutkan ke dalam $50 \mathrm{~mL}$ akuades steril dan disterilisasi secara terpisah pada suhu 115 ${ }^{\circ} \mathrm{C}$ selama 10 menit (Pyar \& Peh 2014). Sampel dengan komposisi yang sama kemudian dikeringkan menggunakan alat freeze dryer pada suhu $-50^{\circ} \mathrm{C}$ dan spray dryer pada suhu inlet $170{ }^{\circ} \mathrm{C}$ dan outlet 70 ${ }^{\circ} \mathrm{C}$. Produk starter yang dihasilkan ditentukan kadar airnya menggunakan metode gravimetric (AOAC 1995)

Viabilitas Starter. Perhitungan jumlah sel dilakukan dengan metode sebar (pour plate). Kultur kering disuspensikan dengan larutan garam fisiologis steril dan dihomogenkan dengan vortex selama 30 menit sebelum dibuat beberapa seri pengenceran, kemudian disebar sebanyak $100 \mu \mathrm{L}$ pada media MRSA dan diinkubasi pada suhu $37^{\circ} \mathrm{C}$ selama 48 jam. Jumlah koloni dihitung dan dinyatakan dalam $\log \mathrm{CFU} / \mathrm{g}$.

Tingkat Ketahanan Sel (Survival Rate). Survival rate LAB (\%) setelah dehidrasi dihitung menggunakan persamaan (N/No) x 100\% (Leja et al. 2009). No merupakan jumlah sel (CFU/g) sebelum proses pengeringan. $\mathrm{N}$ merupakan jumlah sel (CFU/g) setelah pengeringan.

Stabilitas Selama Penyimpanan. Kultur kering hasil pengeringan terpilih dikemas di dalam alumunium foil kedap udara kemudian disimpan pada suhu dingin $\left(4^{\circ} \mathrm{C}\right)$ dan suhu ruang $\left(28^{\circ} \mathrm{C}\right)$ selama 4 minggu. Viabilitas sel pada kultur kering dihitung pada hari ke-0, 7, 14, 21 dan 28 setelah penyimpanan. Jumlah koloni dinyatakan dalam log CFU/g.

Analisis Statistik. Data ditampilkan dalam bentuk rataan \pm standar deviasi dari tiga ulangan perlakuan. Analisis statistik dihitung dengan analisis Rancangan
Acak Lengkap (RAL) faktorial menggunakan software SAS (Statistical Analytic Software version 9.1). Uji Duncan dilakukan sebagai uji lanjut untuk mengidentifikasi secara statistik perbedaan yang signifikan dalam percobaan $(\alpha=0.05)$.

\section{HASIL}

Seleksi BAL. Hasil seleksi isolat BAL lokal terhadap kemampuan produksi asam dan sensitivitas antibiotik menunjukkan bahwa hanya tiga dari sebelas isolat yang tidak resisten terhadap tiga antibiotik yang diujikan, dua diantaranya memiliki total asam yang tinggi yaitu isolat E1222 dan D4 (Tabel 1 dan 2). Dua isolat hasil seleksi awal data kuantitatif total asam dan $\mathrm{pH}$ selama proses fermentasi (E1222 dan D4) kemudian diseleksi secara kualitatif berdasarkan produksi asam laktat tertinggi menggunakan HPLC. Hasil HPLC menunjukkan bahwa isolat E1222 memproduksi asam laktat lebih tinggi (16397.54 $\mathrm{mg} / \mathrm{L}$ ) dibandingkan dengan isolat D4 (14458.28

Tabel 1. Kemampuan produksi asam isolat BAL yang dikulturkan pada media MRSB pada suhu $37^{\circ} \mathrm{C}$ selama 48 jam

\begin{tabular}{lcc}
\hline Isolat & Total asam $(\mathrm{mg} / \mathrm{mL})$ & $\mathrm{pH}$ \\
\hline E 1212 & $24.96 \pm 0.00$ & $4.46 \pm 0.04$ \\
E 1211 & $21.12 \pm 0.00$ & $4.26 \pm 0.02$ \\
E 2211 & $22.08 \pm 1.36$ & $4.43 \pm 0.05$ \\
E 2113 & $21.12 \pm 0.00$ & $4.51 \pm 0.03$ \\
E 2112 & $22.08 \pm 1.36$ & $4.51 \pm 0.08$ \\
E 1222 & $25.92 \pm 1.36$ & $4.47 \pm 0.00$ \\
E 2121 & $23.04 \pm 0.00$ & $4.43 \pm 0.00$ \\
D 3 & $25.92 \pm 1.36$ & $4.40 \pm 0.01$ \\
D 4 & $29.76 \pm 1.36$ & $4.32 \pm 0.03$ \\
D 5 & $28.80 \pm 0.00$ & $4.33 \pm 0.02$ \\
D 7 & $1.92 \pm 0.00$ & $5.89 \pm 0.00$ \\
\hline
\end{tabular}

Tabel 2. Sensitivitas antibiotik isolat BAL yang ditumbuhkan pada media MRSA pada suhu $37{ }^{\circ} \mathrm{C}$ selama 48 jam

\begin{tabular}{|c|c|c|c|c|c|c|c|}
\hline \multirow{3}{*}{ Isolat } & \multicolumn{6}{|c|}{ Antibiotik } & \multirow{3}{*}{ Isolat terpilih } \\
\hline & \multicolumn{2}{|c|}{ Tetrasiklin } & \multicolumn{2}{|c|}{ Eritromisin } & \multicolumn{2}{|c|}{ Kloramfenikol } & \\
\hline & $\mathrm{d}(\mathrm{mm})$ & Hasil & $\mathrm{d}(\mathrm{mm})$ & Hasil & $\mathrm{d}(\mathrm{mm})$ & Hasil & \\
\hline E 1212 & 0 & $\mathrm{R}$ & 0 & $\mathrm{R}$ & 0 & $\mathrm{R}$ & - \\
\hline E 1211 & 17 & I & 15 & I & 20 & S & $\sqrt{ }$ \\
\hline E 2211 & 15 & I & 12 & $\mathrm{R}$ & 20 & S & - \\
\hline E 2113 & 0 & $\mathrm{R}$ & 0 & $\mathrm{R}$ & 0 & $\mathrm{R}$ & - \\
\hline E 2112 & 0 & $\mathrm{R}$ & 0 & $\mathrm{R}$ & 0 & $\mathrm{R}$ & - \\
\hline E 1222 & 15 & I & 15 & I & 20 & $\mathrm{~S}$ & $\sqrt{ }$ \\
\hline E 2121 & 0 & $\mathrm{R}$ & 0 & $\mathrm{R}$ & 0 & $\mathrm{R}$ & - \\
\hline D 3 & 0 & $\mathrm{R}$ & 0 & $\mathrm{R}$ & 0 & $\mathrm{R}$ & - \\
\hline D 4 & 17 & I & 15 & I & 18 & $\mathrm{~S}$ & $\sqrt{ }$ \\
\hline D 5 & 0 & $\mathrm{R}$ & 0 & $\mathrm{R}$ & 0 & $\mathrm{R}$ & - \\
\hline D 7 & 0 & $\mathrm{R}$ & 0 & $\mathrm{R}$ & 0 & $\mathrm{R}$ & - \\
\hline
\end{tabular}

* Interpretasi diameter zona hambat berdasarkan Johnson dan Case (2007) : Tetrasiklin (30 $\mu \mathrm{g})$ Sensitif (diameter zona hambat $\geq$ $19 \mathrm{~mm}$ ), Intermediet $(18 \mathrm{~mm} \geq$ diameter zona hambat $\geq 15 \mathrm{~mm}$ ), Resisten (diameter zona hambat $\leq 14 \mathrm{~mm})$; Eritromisin $(15 \mu \mathrm{g})$ Sensitif (diameter zona hambat $\geq 23 \mathrm{~mm}$ ), Intermediet $(22 \mathrm{~mm} \geq$ diameter zona hambat $\geq 14 \mathrm{~mm}$ ), Resisten (diameter zona hambat $\leq 13 \mathrm{~mm}$ ); Kloramfenikol $(30 \mu \mathrm{g}$ ) Sensitif (diameter zona hambat $\geq 18 \mathrm{~mm})$, Intermediet $(16 \mathrm{~mm} \geq$ diameter zona hambat $\geq 14$ $\mathrm{mm}$ ), Resisten (diameter zona hambat $\leq 12 \mathrm{~mm}$ ). 
$\mathrm{mg} / \mathrm{L}$ ) (Tabel 5). Isolat E1222 kemudian digunakan sebagai isolat terpilih yang digunakan untuk tahap selanjutnya.

Pengamatan mikroskopis menunjukkan bahwa isolat E1222 bersifat Gram positif dan berbentuk kokus. Isolat E1222 mencapai tingkat pertumbuhan spesifik maksimal $\left(\mu_{\mathrm{m}}=0.027 \mathrm{~h}^{-1}\right)$ pada jam ke-6 pengamatan (Gambar 1). Oleh karena itu, pada perlakuan selanjutnya inokulum kultur yang digunakan untuk enkapsulasi berumur 6 jam.

Viabilitas dan Tingkat Ketahanan Sel Setelah Freeze Drying dan Spray Drying. Viabilitas dan tingkat ketahanan sel setelah proses freeze drying lebih tinggi dibandingkan setelah proses spray drying (Tabel 3 dan Tabel 4), namun viabilitas kultur kering hasil spray drying masih memenuhi standar minimal starter yaitu $10^{7} \mathrm{CFU} / \mathrm{g}$ (Tabel 3). Hasil pengeringan menggunakan spray dryer menunjukkan kadar air kultur kering yang lebih rendah jika dibandingkan dengan hasil pengeringan menggunakan freeze dryer (Tabel 3), namun hasil analisis statsistik menunjukkan bahwa semua perlakuan memberikan pengaruh yang berbeda terhadap respon kadar air.

Stabilitas Selama Penyimpanan. Starter kering hasil freeze drying dipilih untuk uji stabilitas penyimpanan karena menghasilkan viabilitas sel yang lebih tinggi. Suhu penyimpanan $28{ }^{\circ} \mathrm{C}$ mewakili penyimpanan di suhu ruang sedangkan suhu $4{ }^{\circ} \mathrm{C}$ mewakili penyimpanan suhu lemari pendingin (refrigerator). Penurunan viabilitas sel lebih besar terjadi pada penyimpanan suhu $28{ }^{\circ} \mathrm{C}$ dibandingkan pada suhu $4{ }^{\circ} \mathrm{C}$ (Gambar 2). Viabilitas sel kultur kering pada penyimpanan suhu $28{ }^{\circ} \mathrm{C}$ bahkan mengalami penurunan hingga $0 \%$ selama empat minggu. Namun, kultur kering hasil freeze

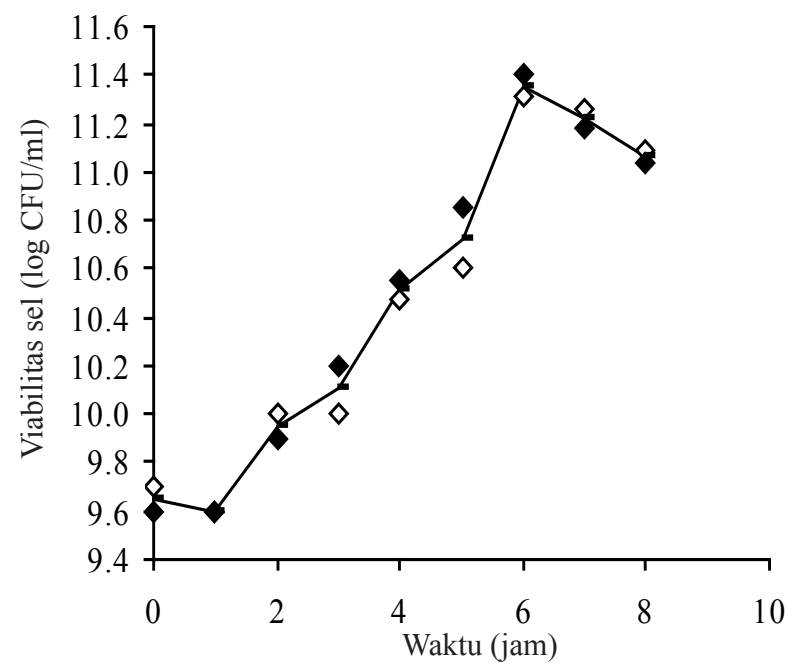

Gambar 1. Kurva tumbuh isolat Pediococcus pentosaceus yang ditumbuhkan pada media MRSB pada suhu $37^{\circ} \mathrm{C}$.

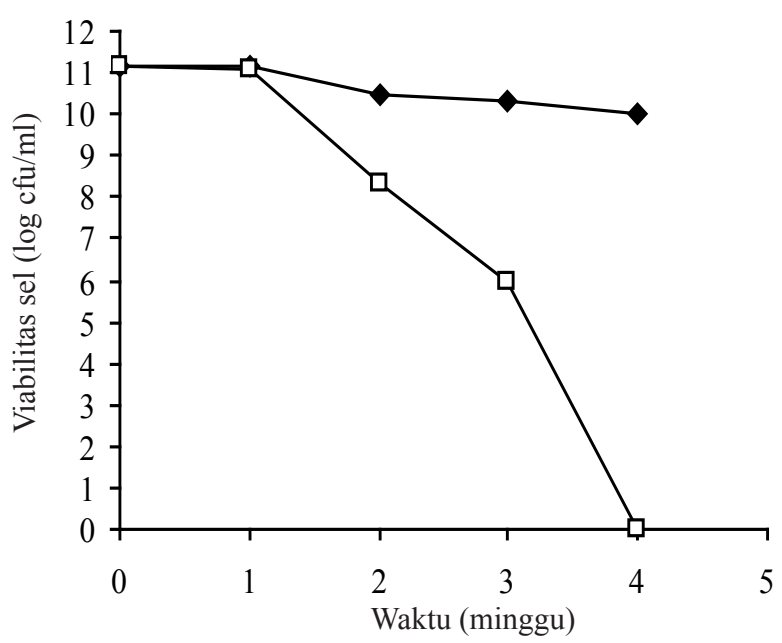

Gambar 2. Viabilitas sel Pediococcus pentosaceus selama penyimpanan empat minggu pada suhu $28^{\circ} \mathrm{C}$ (๑-) dan suhu $4{ }^{\circ} \mathrm{C}(\neg-)$.

Tabel 3. Viabilitas sel bakteri dan kadar air kultur kering setelah freeze drying dan spray drying menggunakan matrik tapioka asam

\begin{tabular}{lcccc}
\hline \multirow{2}{*}{ Matriks } & \multicolumn{2}{c}{ Viabilitas sel (log CFU/g) } & \multicolumn{2}{c}{ Kadar air (\%) } \\
\cline { 2 - 5 } & Freeze drying & Spray drying & Freeze drying $^{\text {Spray drying }}$ \\
\hline Tapioka asam & $10.34 \pm 0.03^{\mathrm{b}}$ & $8.91 \pm 0.30^{\mathrm{c}}$ & $22.16 \pm 0.18^{\mathrm{a}}$ & $10.86 \pm 0.48^{\mathrm{c}}$ \\
Tapioka asam $+10 \%$ susu skim & $11.31 \pm 0.11^{\mathrm{a}}$ & $9.12 \pm 0.11^{\mathrm{c}}$ & $15.09 \pm 0.06^{\mathrm{b}}$ & $7.26 \pm 0.62^{\mathrm{d}}$ \\
\hline
\end{tabular}

Tabel 4. Ketahanan sel bakteri kultur kering setelah freeze drying dan spray drying menggunakan matrik tapioka asam

\begin{tabular}{lcc}
\hline \multirow{2}{*}{ Matriks } & \multicolumn{2}{c}{ Tingkat ketahanan sel (\%) } \\
\cline { 2 - 3 } & Freeze drying & Spray drying \\
\hline Tapioka asam & $89 \pm 0.002^{\mathrm{b}}$ & $76 \pm 0.026^{\mathrm{c}}$ \\
Tapioka asam $+10 \%$ susu skim & $97 \pm 0.091^{\mathrm{a}}$ & $78 \pm 0.097^{\mathrm{c}}$ \\
\hline
\end{tabular}

Tabel 5. Produksi asam laktat isolat E1222 dan isolat D4 yang dikulturkan pada media MRSB pada suhu $37{ }^{\circ} \mathrm{C}$ selama 48 jam menggunakan HPLC

\begin{tabular}{llll}
\hline Sampel & Luas Area $(\mathrm{y})$ & Waktu Retensi (menit) & Konsentrasi Asam Laktat (x) (mg/L; ppm) \\
\hline E1222 & 34580,00 & 4,004 & 16397,54 \\
D4 & 33457,00 & 4,015 & 14458,28 \\
\hline
\end{tabular}


drying menggunakan matriks tapioka asam hanya mengalami penurunan viabilitas sel hingga $89.38 \%$ selama empat minggu pada penyimpanan suhu $4{ }^{\circ} \mathrm{C}$.

\section{DISKUSI}

Perkembangan industri makanan fermentasi dan didukung oleh tingginya minat masyarakat untuk mengkonsumsi makanan fermentasi menyebabkan tingginya kebutuhan terhadap kultur starter untuk produksi. Dibandingkan dengan starter cair, penggunaan kultur starter kering lebih menguntungkan karena dapat disimpan lebih lama dan tidak perlu diremajakan berulang-ulang selama penggunaan. BAL merupakan kelompok mikroorganisme yang paling banyak digunakan sebagai kultur starter, namun tidak semua BAL dapat digunakan sebagai starter karena tidak aman dikonsumsi dan tidak optimal dalam meningkatkan kualitas produk (Hummel et al. 2007; Kastner et al. 2006; Stanbury \& Whitaker 1984; Leroy \& De Vuyst 2004).

Sensitivitas antibiotik merupakan kriteria penting dalam seleksi BAL untuk produksi starter (Hummel et al. 2007; Stanbury \& Whitaker 1984). Penggunaan BAL resisten antibiotik sebagai starter dapat menyebabkan penyebaran sifat resisten terhadap bakteri lain. BAL dapat menjadi reservoir gen resisten antibiotik dan mentransfernya pada bakteri patogen maupun BAL lain (Toomey et al. 2010). Transmisi gen resisten antibiotik pada bakteri patogen dapat menyebabkan penurunan efektivitas penggunaan antibiotik dalam pengobatan, sedangkan transmisi pada BAL lain dapat meningkatkan penyebaran sifat resisten antibiotik.

Resistensi terhadap tetrasiklin, eritromisin dan kloramfenikol telah ditemukan pada BAL yang digunakan sebagai starter fermentasi produk makanan (Hummel et al. 2007). Sifat resisten terhadap antibiotik dapat terjadi melalui mekanisme yang berbeda, diantaranya yaitu (1) penurunan penyerapan antibiotik; (2) inaktivasi atau modifikasi target antibiotik; (3) pengenalan target baru antibiotik; (4) hidrolisis antibiotik; (5) modifikasi antibiotik dan (6) pencegahan aktivasi antibiotik (Normark \& Norkmark 2002). Sifat resisten antibiotik pada BAL dikodekan oleh gen yang terdapat pada plasmid konjugatif dan transposon (Mathur \& Singh 2005). Gen tet $(\mathrm{M})$ yang membawa sifat resisten tetrasiklin dideteksi pada Lactobacullus plantarum E14 dan gen tet(L) pada Pediococcus parvulus (RojoBezares et al. 2006). Gen erm(B) yang membawa sifat resisten eritromisin dideteksi keberadaannya pada Pediococcus acidilactici J83 (Rojo-Bezares et al. 2006). Gen cat yang membawa sifat resisten kloramfenikol ditemukan keberadaannya pada plasmid pRE25 Enterococcus faecalis RE25 (Schwatz et al. 2001). Transmisi gen resisten antibiotik dapat terjadi secara konjugasi di antara sesama BAL. Perreten et al. (1997) menyatakan bahwa transposon TnFO1 pada Enterococcus faecalis yang membawa gen tet $(\mathrm{M})$ dapat ditransfer secara konjugasi pada bakteri Gram positif lain. Isolat E1222 pada penelitian ini menunjukkan sensitivitas terhadap tetrasiklin, eritromisin dan kloramfenikol. Hasil identifikasi oleh Meryandini dan Wiryawan (2013) menunjukkan bahwa isolat E1222 ialah Pediococcus pentosaceus. Rojo-Bezares et al. (2006) juga melaporkan bahwa empat galur $P$. pentosaceus yang diuji menunjukan sensitivitas terhadap tetrasiklin, eritromisin, dan kloramfenikol.

Produktivitas BAL sebagai starter dalam proses fermentasi dapat diketahui dari kemampuan BAL tersebut memproduksi asam laktat. Hasil HPLC menunjukkan bahwa pada media kaldu MRS, isolat P. pentosaceus mampu memproduksi asam laktat sebesar $16397.54 \mathrm{mg} / \mathrm{L}$. BAL mampu mengubah glukosa melalui jalur fermentasi menghasilkan asam laktat sebagai produk akhirnya. Fermentasi merupakan proses pembentukan energi melalui transfer elektron di sitoplasma (fosforilasi tingkat substrat) (White 2007). Fermentasi dapat terjadi pada kondisi ketiadaan akseptor elektron respiratif. Hal ini menyebabkan proses fermentasi harus memproduksi akseptor elektron (electron sinks) yang digunakan untuk menangkap elektron dari NADH selama proses oksidasi.

Starter yang dihasilkan berasal dari kultur berumur enam jam, yaitu saat mencapai laju pertumbuhan spesifik maksimum, yaitu pada waktu tersebut sel memasuki akhir fase logaritmik menuju awal fase stationer (Gambar 1). BAL yang memasuki fase stasioner mampu membangun mekanisme stress-resistant sebagai pertahanan terhadap kondisi lingkungan rendah glukosa (fase stasioner) dengan mensintesis glucose starvation-induced protein (Van de Guchte et al. 2002). Giard et al. (2001) melaporkan adanya glucose starvation-induced protein pada Enterococcus faeclis yaitu manganase superoxide dismutase yang berperan sebagai proteksi terhadap stress oksidatif.

Kultur kering hasil pengeringan menggunakan freeze dryer memiliki viabilitas lebih tinggi dibandingkan dengan menggunakan spray dryer (Tabel 3). Hal ini menunjukkan bahwa P. pentosaceus lebih mampu bertahan terhadap kerusakan akibat 
suhu dingin dibandingkan suhu panas. Harmayani et al. (2001) juga melaporkan bahwa viabilitas sel kultur kering BAL hasil freeze drying lebih tinggi dibandingkan dengan viabilitas sel kultur kering hasil spray drying. Kerusakan sel selama proses pengeringan beku (freeze drying) dapat disebabkan oleh perubahan kondisi fisik lipid pada membran sel dan perubahan struktur protein yang sensitif di dalam sel (Carvalho et al. 2004). Perubahan tersebut menyebabkan sel mengalami perubahan fisiologi meliputi penurunan fluiditas membran sel serta penurunan stabilitas struktur sekunder RNA dan DNA yang menyebabkan terjadinya reduksi efisiensi translasi, transkripsi dan replikasi DNA (Santivarangkna et al. 2008b). Kerusakan sel selama proses pengeringan semprot (spray drying) dapat disebabkan oleh stress terhadap suhu tinggi dan dehidrasi (Fu \& Chen 2011). Paparan suhu tinggi menyebabkan perubahan struktur makromolekul seperti protein dan asam nukleat, sedangkan stress dehidrasi menyebabkan perubahan fluiditas membran sitoplasma yang mengakibatkan oksidasi lipid (Corcoran et al. 2008; Santivarangkna et al. 2008b). Matriks merupakan salah satu faktor yang mempengaruhi tingkat ketahanan sel selama proses pengeringan. Dehidrasi selama proses pengeringan dapat menyebabkan membran sel mengalami kerusakan sehingga terjadi kebocoran sel. Padatan matriks yang terbentuk selama proses pengeringan dapat mencegah terjadinya kerusakan sel tersebut (Keivani et al. 2014). Penggunaan tapioka asam sebagai matriks pada penelitian ini mampu mempertahankan tingkat ketahanan sel (\% survival rate) hingga 89\%-76\% (Tabel 4). Tapioka asam (sour cassava starch) merupakan pati termodifikasi hasil fermentasi tapioka alami (native cassava starch). Pati tapioka terdiri atas dua komponen polisakarida utama yaitu amilosa dan amilopektin. Selama proses fermentasi terjadi pemutusan struktur amilosa pada pati sehingga membentuk gula sederhana. Tingginya gula sederhana pada tapioka asam dapat berperan sebagai protektan BAL, sebagaimana dilaporkan Santivarangkna et al. (2008a) yang menyatakan bahwa gula dapat berperan sebagai protektan yang mampu mempertahankan viabilitas sel selama enkapsulasi dan pengeringan serta penyimpanan. Pengaruh gula terhadap viabilitas sel selama proses pengeringan dapat melalui beberapa mekanisme. Pertama, melindungi dari kebocoran membran yang terjadi akibat adanya perubahan fase membran. Kebocoran sel dapat terjadi selama dehidrasi sel kering karena membran yang berada pada fase gel di suhu ruang akan mengalami perubahan menjadi fase kristalin. Kedua, menekan peluang terjadinya cryoinjuries, thermal-injuries dan kerusakan membran selama proses pengeringan (Santivarangkna et al. 2008a).

Starter kering hasil freeze drying menunjukkan viabilitas dan ketahanan sel lebih tinggi dibandingkan dengan spray drying. Viabilitas sel starter kering hasil freeze drying selama penyimpanan empat minggu pada suhu $4{ }^{\circ} \mathrm{C}$ masih dapat dipertahankan hingga $89.38 \%$ (Gambar 2). Hal ini berbeda dengan starter kering hasil freeze drying yang disimpan pada suhu $28^{\circ} \mathrm{C}$, dimana terjadi penurunan viabilitas sel hingga $0 \%$ selama empat minggu penyimpanan. Suhu penyimpanan kultur kering sangat berpengaruh terhadap tingkat penurunan viabilitas sel selama penyimpanan (Carvalho et al. 2004). Wang et al. (2004) mendapatkan hasil yang sama dalam penelitiannya bahwa kultur kering Streptococcus thermophillus dan Lactobacillus acidophillus menghasilkan viabilitas kultur lebih tinggi pada suhu penyimpanan $4{ }^{\circ} \mathrm{C}$. Penyebab utama penurunan viabilitas sel selama penyimpanan ialah terjadinya oksidasi lipid (Santivarangkna et al. 2008b). Makromolekul yang essensial seperti lipid dan protein selama proses penyimpanan mengalami degradasi secara alami. Lipid dan protein di dalam sel mengalami oksidasi dan denaturasi berturut-turut selama waktu penyimpanan. Pada suhu yang lebih tinggi, terjadi peningkatan oksidasi lipid sehingga menyebabkan komposisi asam lemak jenuh pada membran meningkat yang berakibat pada fluiditas membran sel menurun. Hal ini menyebabkan terjadinya kebocoran membran sel sehingga viabilitas sel selama penyimpanan mengalami penurunan. Penyimpanan jangka panjang kultur kering sangat dipengaruhi oleh kondisi penyimpanan, yaitu suhu dan kadar air (Santivarangkna et al. 2008b). Penyimpanan pada suhu $4^{\circ} \mathrm{C}$ dapat menghambat terjadinya oksidasi lipid dan kerusakan sel. Kondisi penyimpanan kedap udara juga mampu mempertahankan kadar air starter kering dan melindungi dari paparan oksigen berlebih sehingga dapat mengurangi terjadinya oksidasi lipid. Hasil penelitian ini menunjukkan bahwa kultur kering $P$. pentosaceus menggunakan matriks tapioka asam lebih baik diproduksi menggunakan freeze dryer dan disimpan pada suhu $4{ }^{\circ} \mathrm{C}$.

\section{UCAPAN TERIMA KASIH}

Penelitian ini didukung oleh program Beasiswa Unggulan (BU) Direktorat Jenderal Pendidikan Tinggi (Ditjen Tinggi) Kementerian Pendidikan dan Kebudayaan kepada Ira Erdiandini dan program 
Penelitian Unggulan Strategis Nasional tahun 2012-2013, No: 69/IT3.41.2/L1/SPK/2013 oleh Direktorat Jenderal Pendidikan Tinggi (Ditjen Tinggi) Kementerian Pendidikan dan Kebudayaan kepada Dr. Titi Candra Sunarti.

\section{REFERENSI}

[AOAC] Association of Official Analytical Chemists. 1995. Official Methods of Analysis.16th ed. New York (US) : AOAC International.

Burgain C, Gaiani C, Linder M, Scher J. 2011. Encapsulation of probiotic living cells: from laboratory scale to industrial applications. J Food Eng 104: 467-483.

Carvalho AS, Silva J, Ho P, Teixeira P, Malcata FX, Gibbs P. 2004. Relefant factors for the preparation of freeze-dried lactic acid bacteria. Int Dairy J 14: 835-847.

Corcoran BM, Stanton C, Fitzgerald G, Ross RP. 2008. Life under stress: the probiotic stress response and how it may be manipulated. Curr Pharm Design 14: 1382-1399.

Fu N, Chen XD. 2011. Towards maximal cell survival in convective thermal drying processes. Food Res Int 44: 1127-1149.

Gbassi GK, Vandamme T. 2012. Probiotic encapsulation technology from microencapsulation to release into the gut. Pharmaceutics 4: 149-163.

Giard JC, Laplace JM, Rince A, Pichereau V, Benachour A, Leboeuf C, Flahaut S, Auffray Y, Hartke A. 2001. The stress proteome of Enterococcus faecalis. Electrophor 22: 2947-2954.

Gomez-Ruiz JA, Cabezas L, Martinez-Castro I, Gonzales-Vinas MA, Poveda JM. 2008. Influence of a defined-strain starter and Lactobacillus plantarum as adjunct culture on volatile compounds and sensory characteristics of manchego cheese. Eur Food Res Technol 227: 181-190.

Harmayani E, Ngatirah, Rahayu ES, Utami T. 2001. Ketahanan dan viabilitas probiotik bakteri asam laktat selama proses pembuatan kultur kering dengan metode freeze dan spray drying. J Teknol Industri Pangan 12: 126-132.

Hummel AS, Hertel C, Holzapfel WH, Franz CMAP. 2007. Antibiotic resistances of starter and probiotic strains of lactic acid bacteria. Appl Environ Microbiol 73: 730-739.

Johnson TR, Case CL. 2007. Laboratory experiments in microbiology. $8^{\text {th }}$ edition. San Francisco (US): Pearson Benjamin Cummings.

Kastner S, Perreten V, Bleuler H, Hugenschmidt G, Lacroix C, Meile L. 2006. Antibiotic susceptibility patterns and resistance genes of starter cultures and probiotic bacteria used in food. Syst Appl Microbiol 29: 145-155.

Keivani F, Mokarram RR, Gholian MM, Benis KZ, Zendeboodi F, Zadeh SS. 2014. An encyclopedic approach to distinguish the survival of probiotic living cells during drying processes. Wudpecker J Med Sci 3: 001-007.

Leja K, Dembczynski R, Bialas W, Jankowski T. 2009. Production of dry Lactobacillus rhamnosus GG preparations by spray drying and lyophilization in aqueous two-phase systems. Acta Sci Pol Technol Aliment 8: 39-49.

Leroy F, De Vuyst L. 2004. Lactic acid bacteria as functional starter cultures for the food fermentation industry. Trends Food Sci Technol 15: 67-78.

Lian WC, Hsiao HC, Chou CC. 2002. Survival bifidobacteria after spray-drying. Int J Food Microbiol 74: 79-86.
Liu G, Griffiths MW, Shang N, Chen S, Li P. 2010. Applicability of bacteriocinogenic Lactobacillus pentosus 31-1 as a novel functional starter culture or coculturefor fermented sausage manufacture. J Food Protect 73: 292-298.

Mathur S, Singh R. 2005. Antibiotic resistance in food lactic acid bacteria-a review. Int J Food Microbiol 105: 281-295.

Meryandini A, Wiryawan KG. 2013. Penapisan bakteri asam laktat sebagai probiotik ayam. Laporan penelitian unggulan Perguruan Tinggi sesuai mandat pusat LPPM IPB. Bogor (ID): IPB. (Belum dipublikasikan)

Morgan CA, Herman N, White PA, Vesey G. 2006. Preservation of micro-organisms by drying; a review. J Microbiol Methods 66: 183-193.

Nazzaro F, Orlando P, Fratianni F, Coppola R. 2012. Microencapsulation in food science and biotechnology. Curr Opinion Biotechnol 23: 182-186.

Normark BH, Normark S. 2002. Evolution and spread of antibiotic resistance. $J$ Int Med 252: 91-106.

Peighambardoust SH, Tafti AG, Hesari J. 2011. Application of spray drying for preservation of lactic acid starter cultures: a review. Trends Food Sci Technol 22: 215-224.

Perreten V, Kolloffel B, Teuber M. 1997. Conjugal transfer of the Tn916-like transposon TnFO1 from Enterococcus faecalis isolated from cheese to other Gram-positive bacteria. Syst Appl Microbiol 20: 27-38.

Putri WDR, Haryadi DW, Marseno, Cahyanto MN. 2011. Effect of biodegradation by lactic acid bacteria on physical properties of cassava starch. Int Food Res J 18: 1149-1154.

Pyar H, Peh KK. 2014. Cost effectiveness of cryoprotective agents and modified de-man rogosa sharpe medium on growth of Lactobacillus acidophilus. Pak J Biol Sci 17: $462-471$.

Rojo-Bezares B, Saenz Y, Poeta P, Zarazaga M, Ruiz-Larrea F, Torres C. 2006. Assessment of antibiotic susceptibility within lactic acid bacteria strains isolated from wine. Int $J$ Food Microbiol 111: 234-240.

Rosyidah E. 2013. Isolasi bakteri asam laktat dan selulolitik serta aplikasinya untuk meningkatkan kualitas tepung jagung [Thesis]. Bogor (ID) : Institut Pertanian Bogor.

Santivarangkna C, Higl B, Foerst P. 2008a. Protection mechanisms of sugars during different stages of preparation process of dried lactic acid starter cultures. Food Microbiol. 25: 429-441.

Santivarangkna C, Kulozik U, Foerst P. 2008b. Inactivation mechanisms of lactic acid starter cultures cultures preserved by drying process. J Appl Microbiol 105: 1-13.

Schnurer J, Magnusson J. 2005. Antifungal lactic acid bacteria as biopreservatives. Trends Food Sci Technol 16: 70-78.

Schwatz FV, Perreten V, Teuber M. 2001. Sequence of the 50-kb conjugative multiresistance plasmid pRE25 from Enterococcus faecalis RE25. Plasmid 46: 170-187.

Stanbury PF, Whitaker A. 1984. Principles of fermentation technology. Oxford (GB): Pergamon Press.

Suseno D. 2015. Pemanfaatan isolat bakteri asam laktat indigenous sebagai starter untuk fermentasi sagu [Thesis]. Bogor (ID) : Institut Pertanian Bogor.

Toomey N, Bolton D, Fanning S. 2010. Characterisation and transferability of antibiotic resistance genes from lactic acid bacteria isolated from Irish pork and beef abattoirs. Res Microbiol 161: 127-135.

Van de Guchte M, Serror P, Chervanx C, Smokvina T, Ehrlich SD, Maguin E. 2002. Stress responses in lactic acid bacteria. Antonie van Leeuwenhoek 82: 187-216. 
Wang YC, Yu RC, Chou CC. 2004. Viability of lactic acid bacteria and Bifidobacteria in fermented soymilk after drying, subsequent rehydration and storage. Int $J$ Food Microbiol 92: 209-217.

Wang S, Zhu H, Lu C, Kang Z, Luo Y, Feng L, Lu X. 2012. Fermented milk supplemented with probiotics and prebiotics can effectively alter the intestinal microbiota and immunity of host animals. J Dairy Sci 95: 4813-4822.

White D. 2007. The physiology and biochemistry of prokaryotes. $3^{\text {rd }}$ ed. New York (US): Oxford University Press.
Winarti C, Sunarti TC, Mangunwidjaja D, Richana N. 2013. Potensi dan Aplikasi Pati Termodifikasi sebagai Bahan Aktif Bahan Matrikss Enkapsulasi Bahan Bioaktif. Buletin Teknol Pascapan Pert 9: 83-94.

Yao AA, Dortu C, Egounlety M, Pinto C, Edward VA, Huch M, Franz CMAP, Holzapfel W, Mbugua S, Mengu M et al. 2009. Production of freeze-dried lactic acid bacteria starter culture for cassava fermentation into gari. Afr J Biotechnol 8: 4996-5004. 